\title{
Fracture properties of high-strength concrete obtained by direct modification of structure
}

\author{
Serhiy Solodkyy ${ }^{1}$, Taras Markiv ${ }^{2}$, Khrystyna Sobol ${ }^{1}$, and Oleksii Hunyak ${ }^{1, *}$ \\ ${ }^{1}$ Lviv Polytechnic National University, Department of Highways and Bridges, Bandery st. 12 S., \\ 79013 Lviv, Ukraine \\ ${ }^{2}$ Lviv Polytechnic National University, Department of Building Production, Bandery st. 12 S., 79013 \\ Lviv, Ukraine
}

\begin{abstract}
High-strength concrete is effectively used worldwide in the last three decades, but it is more brittle in comparison with normal strength concretes. Partial substitution of cement in concrete by active mineral additives and usage of chemical admixture of plasticizing and airentraining action can considerably change their fracture properties. The obtained results show that the increase of the fracture properties is observed in concretes modified with chemical admixtures incorporating mineral additives such as zeolite and limestone due to consolidation of the concrete microstructure. Densification takes place as a result of limiting the amount of calcium hydroxide $(\mathrm{CH})$ due to its reaction with active silica included in the zeolite and the formation of larger amounts of hydrated calcium silicates of tobermorite type as well as calcium hydroaluminate and hydrocarboaluminate with the simultaneous adsorption modification of hydrated products by chemical admixtures.
\end{abstract}

\section{Introduction}

High-strength concrete (HSC) is used in most cases for the construction of high-rise buildings, long-span bridges, etc. According to the American Concrete Institute the concrete with the compressive strength higher than $41 \mathrm{MPa}$ is usually defined as highstrength concrete. In the last three decades it has been effectively applied worldwide. However, HSC tends to be more brittle in comparison with normal strength concretes (NSC) $[1,2]$. Concrete failure is a process of crack formation and growth. Unlike other widespread building materials concrete is a quasi-brittle material, which means that it acts both ways: being brittle (like glass) and elastic-plastic (like steel) simultaneously. The application of linear elastic fracture mechanics (LEFM) and fracture energy approaches are proved to be good mechanisms to predict and prevent failure of cement-based man-made structures. The main fracture properties of concrete can be determined using simple threepoint bend notched beam specimens: critical stress intensity factor $\mathrm{K}_{\mathrm{Ic}}$, fracture energy $\mathrm{G}_{\mathrm{F}}$, and characteristic length $\chi_{\mathrm{tb}}[3]$.

Recent researches have shown [4, 5] that partial substitution of cement in concrete by active mineral additives can considerably change their fracture properties. Usage of these

\footnotetext{
*Corresponding author: oleksii.m.guniak@lpnu.ua
} 
additives does not only allow lowering the environmental harm associated with cement production, but also receiving an economic effect and obtaining a durability improvement in received cement-based composites [6].

Natural zeolite is a promising mineral additive with the relatively high pozzolanic activity [7]. The previous researches [8, 9] of concretes have shown, that namely 10 mass.\% of natural zeolite in combination with chemical admixtures of plasticizing and air-entraining action result in the improvement of concrete properties and durability.

A small amount of limestone is proved to be a good additive due to its high grindability and ability to decrease the temperature of cement hydration [10]. Grains of limestone in combination with zeolite act as a centre of crystallization of hydrated phases [9].

Researches have shown that modification of HSC structure with both mineral additives and chemical admixture of plasticizing and air-entraining action improves the strength and fracture characteristics of hardened concretes made with fresh concrete mixes of stiff consistency [11]. However, such important properties as fracture toughness and fracture energy of zeolite containing high-strength concretes have not been thoroughly researched.

Therefore, the objective of this study is to determine the fracture properties of modified concretes made of fresh concrete mixes of semi-fluid consistency.

\section{Experimental Program}

\subsection{Materials and mix-proportions}

Locally available commercial Portland cement CEM I 42.5R was used in this study as a main binding material. Physical and mechanical properties of the cement were tested according to [12], and the results summarized in Table 1.

Table 1. Physical and mechanical properties of the cement.

\begin{tabular}{|c|c|c|c|c|c|c|}
\hline \multirow{2}{*}{$\begin{array}{c}\text { Specific surface, } \\
\mathrm{m}^{2} / \mathrm{kg}\end{array}$} & \multirow{2}{*}{$\begin{array}{c}\text { Residue on sieve } \\
008, \%\end{array}$} & \multirow{2}{*}{$\begin{array}{c}\text { Water demand, } \\
\%\end{array}$} & \multicolumn{2}{|c|}{$\begin{array}{c}\text { Setting time, } \\
\text { min }\end{array}$} & \multicolumn{2}{|c|}{$\begin{array}{c}\text { Compressive } \\
\text { strength, MPa }\end{array}$} \\
\cline { 4 - 7 } & 1.6 & 29.5 & 150 & 210 & 25.4 & 52.6 \\
\hline 340 & 1 initial & final & 2 days & 28 days \\
\hline
\end{tabular}

Chemical compositions of Portland cement, natural zeolite derived from Sokyrnytsia (Ukraine), limestone coming from Mykolaiv quarry were determined by X-ray spectrometer ARL $9800 \mathrm{XP}$ and presented in Table 2. Clinoptilolite content in zeolite was $65 \%$.

Table 2. Chemical composition of cement, zeolite and limestone.

\begin{tabular}{|r|c|c|c|c|}
\hline \multicolumn{2}{|c|}{ Material } & CEM I 42,5R & Natural zeolite & Limestone \\
\hline \multirow{3}{*}{$*$} & $\mathrm{SiO}_{2}$ & 21.49 & 77.64 & 1.95 \\
\cline { 2 - 5 } & $\mathrm{Al}_{2} \mathrm{O}_{3}$ & 4.85 & 13.04 & 0.51 \\
\cline { 2 - 5 } & $\mathrm{Fe}_{2} \mathrm{O}_{3}$ & 3.59 & 2.90 & 0.36 \\
\cline { 2 - 5 } & $\mathrm{CaO}$ & 64.54 & 4.77 & 54.66 \\
\cline { 2 - 5 } & $\mathrm{MgO}$ & 1.44 & 1.60 & 0.52 \\
\cline { 2 - 5 } & $\mathrm{SO}_{3}$ & 1.60 & 0.05 & 0.53 \\
\cline { 2 - 5 } & $\mathrm{LOI}$ & 2.49 & - & 41.47 \\
\hline \multirow{2}{*}{}
\end{tabular}

The river sand with fineness modulus of 1.8 was used as a fine aggregate. The coarse aggregate of irregular shape was used for the research. Bulk density of coarse and fine aggregate was 1420 and $1440 \mathrm{~kg} / \mathrm{m}^{3}$, respectively, voidage was $45 \%$ for both aggregates. 
Commercially available polycarboxylate-based superplasticizer with a specific gravity of 1.05 and solid content of $20 \%$ and an air-entraining agent, based on vinsol resin, with specific gravity of 1.05 and solid content of $4.4 \%$, were used in this study.

The morphology of the investigated materials was examined with the scanning electron microscope SEM FEI Quanta 250 FEG, equipped with EDS.

Four mix-proportions were designed: control mix $\mathrm{C}$ and three mixes (ZL, PA, ZLPA) containing mineral additives and chemical admixtures. Mix-proportions are presented in Table 3.

Table 3. Mix-proportions and fresh concrete mix properties.

\begin{tabular}{|c|c|c|c|c|c|c|c|c|c|c|}
\hline 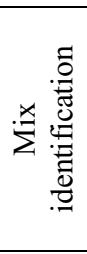 & 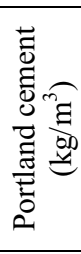 & 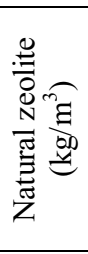 & 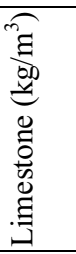 & 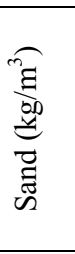 & 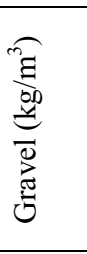 & 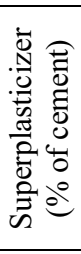 & 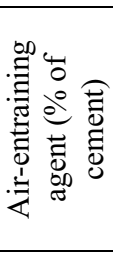 & 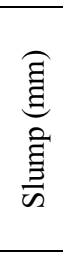 & 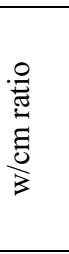 & 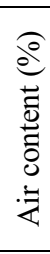 \\
\hline $\mathrm{C}$ & 350.0 & - & - & 600 & 1230 & - & - & 140 & 0.57 & 2.0 \\
\hline ZL & 297.5 & 35 & 17.5 & 600 & 1230 & - & - & 140 & 0.59 & 2.0 \\
\hline PA & 350.0 & - & - & 600 & 1230 & 1 & 0.015 & 140 & 0.50 & 4.2 \\
\hline ZLPA & 297.5 & 35 & 17.5 & 600 & 1230 & 1 & 0.020 & 140 & 0.52 & 3.9 \\
\hline
\end{tabular}

\subsection{Sample Preparations and Test Methods}

Initially, the materials were thoroughly mixed in the required proportions using the laboratory mixer. Water with admixtures was then added and the concrete was mixed up to a uniform state. Subsequently, the fresh concrete was poured into the beam and cubes were moulded. A plate vibrator was used to compact the concrete in the moulds in one layer. Twenty-four hours after casting, the specimens were demoulded and cured for 28 days with the ambient climatic conditions such as temperature of $20 \pm 2^{\circ} \mathrm{C}$ and relative humidity of $95 \%$. The specimens were taken out from the curing tanks after 28 days and then central notches were made using a diamond saw. The size of the prism specimens was $100 * 100 * 400 \mathrm{~mm}$ with an effective span of $380 \mathrm{~mm}$ and a notch-to-depth ratio of 0.40 . The size of cube specimens was $100 * 100 * 100 \mathrm{~mm}$.

An estimate of fracture energy was obtained from the L-d diagram according to the RILEM method (work-of-fracture) [13], the load-displacement history up to failure was recorded by a computer-aided data acquisition system. Fracture parameters were calculated according to the Ukrainian standard DSTU B V.2.7-227 [14].

\section{Results and discussion}

It is well known that during the loading process different defects can be initiated and developed inside the material [15]. Damage, in most cases, begins in the concrete cement matrix or in the interfacial transition zone, namely between cement paste and aggregate. In these studies the effect of concrete structure on the fracture properties of high-strength concrete was studied. As can be seen from Fig. 1, the typical load-deflection curves obtained from fracture test show that, in general, the addition of mineral (zeolite and limestone) additives and chemical (plasticizer and air entraining agent) admixtures in spite of the approximately equal compressive strength (Fig. 2) leads to decrease in maximum load bearing capacity from $4190 \mathrm{~N}$ for the mixture $\mathrm{C}$ to $3910 \mathrm{~N}$ and $3380 \mathrm{~N}$ for mixtures PA and ZL respectively. Since the tensile bending strength is a more sensitive parameter of concrete than the compressive strength the reason may be due to presence of mineral 
particles that act as flaws of microstructure, which can initiate the failure earlier than that concrete without mineral additives. The decrease of area under the load-deflection plot shows that the fracture energy $G_{\mathrm{F}}$ is reduced from $468.59 \mathrm{~J} / \mathrm{m}^{2}$ for control concrete $\mathrm{C}$ to $449.32 \mathrm{~J} / \mathrm{m}^{2}$ for concrete ZL.
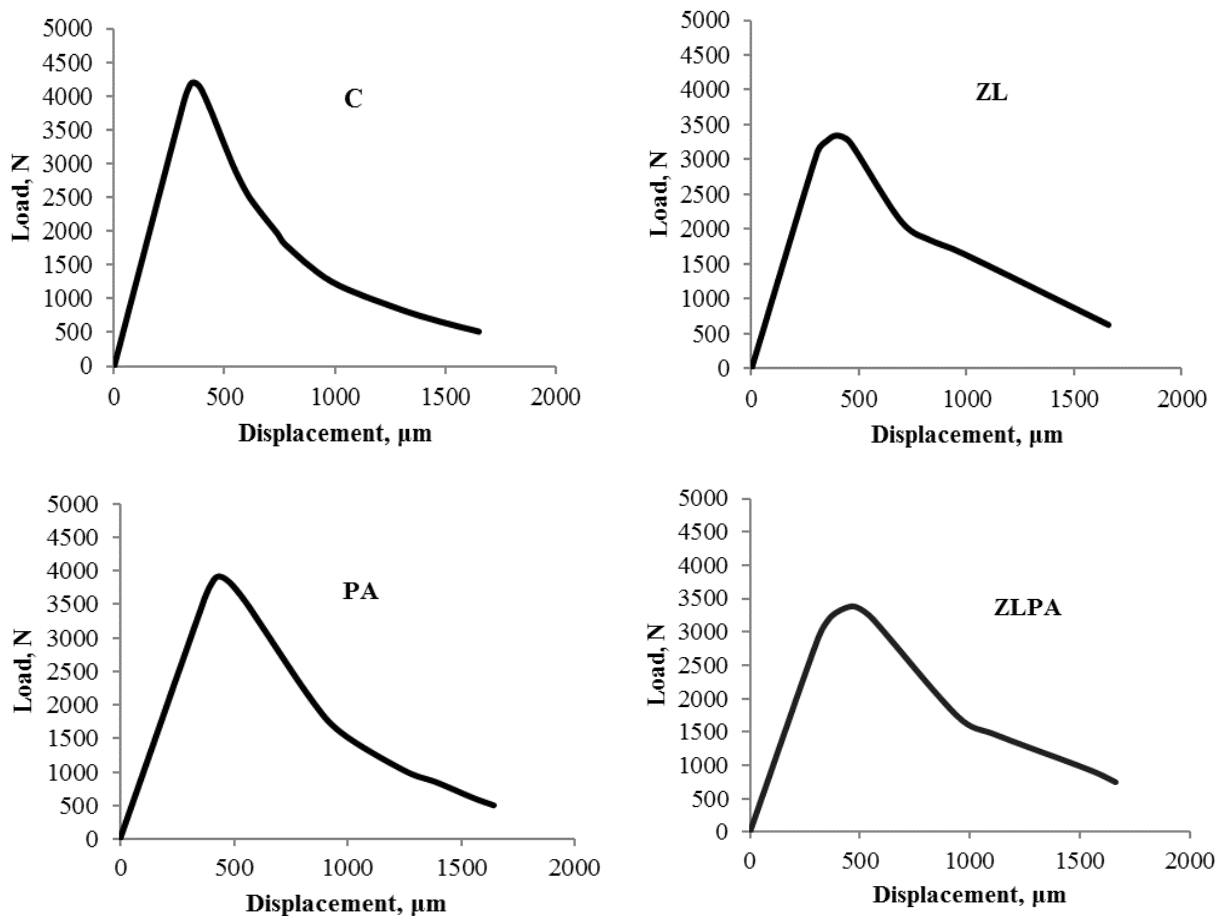

Fig. 1. Typical load-deflection curves for studied concretes.

The air-entraining agent together with superplasticizer in concrete PA has a positive effect on its fracture energy both in subcritical $\left(\mathrm{G}_{\mathrm{i}}\right)$ and post-peak $\left(\mathrm{W}_{\mathrm{L}}\right)$ stages and, as a result, on fracture energy $\mathrm{G}_{\mathrm{F}}$. The modified concrete incorporating zeolite and limestone ZLPA characterizes the highest fracture energy in subcritical $\left(\mathrm{G}_{\mathrm{i}}\right)$ and post-peak $\left(\mathrm{W}_{\mathrm{L}}\right)$ stages and fracture energy $\mathrm{G}_{\mathrm{F}}$.

Table 4. Fracture and mechanical properties of concretes.

\begin{tabular}{|c|c|c|c|c|c|c|c|}
\hline $\begin{array}{c}\text { Mix } \\
\text { identification }\end{array}$ & $\hat{0}^{2} \stackrel{\Xi}{\Xi}$ & 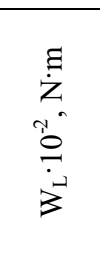 & 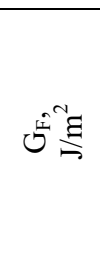 & 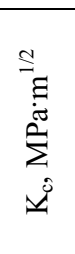 & 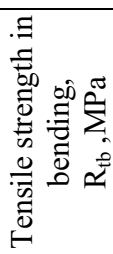 & 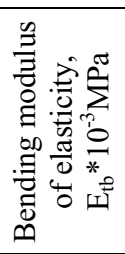 & 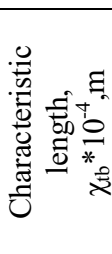 \\
\hline $\mathrm{C}$ & 128.61 & 210.57 & 468.59 & 0.55 & 8.86 & 7.03 & 206 \\
\hline ZL & 129.20 & 214.38 & 449.32 & 0.42 & 7.08 & 8.36 & 252 \\
\hline PA & 148.06 & 217.20 & 497.27 & 0.40 & 8.27 & 8.11 & 190 \\
\hline ZLPA & 163.56 & 219.81 & 521.42 & 0.49 & 7.15 & 9.98 & 238 \\
\hline
\end{tabular}

As seen from the Fig. 2, the compressive strength of concrete ZL incorporating zeolite and limestone is lower than the control concrete $\mathrm{C}$ at its early age of hardening. Concrete PA (without mineral additives) containing plasticizer and air-entraining agent is 
characterized by higher compressive strength both on 3 and 7 days of hardening in comparison with control concrete C. However, the strength of tested concretes is almost leveled with increasing the age and in such a case the fracture energy of designed concretes can be reasonably compared.

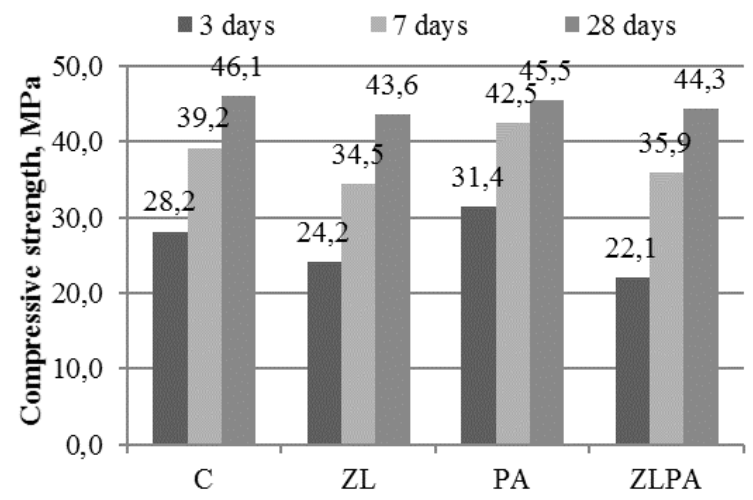

Fig. 2. Compressive strength of concretes.

The physical and mechanical properties of concrete are a direct result of a series of complex processes taking place in microstructure of concrete during hydration. The used electron microscopy method complements the data on the structure formation of cement paste. Microstructure analysis of the cement paste without additives after 28 days of hardening (Fig. 2) shows that microstructure is presented by a large number of hydration products. Some crystals have a fine needle-like or plate-like shape. In some places, dense crystalline blocks of lamellar crystals of Portlandite are observed (Fig. 3a), that is confirmed by the microprobe analysis (Fig. 3b).

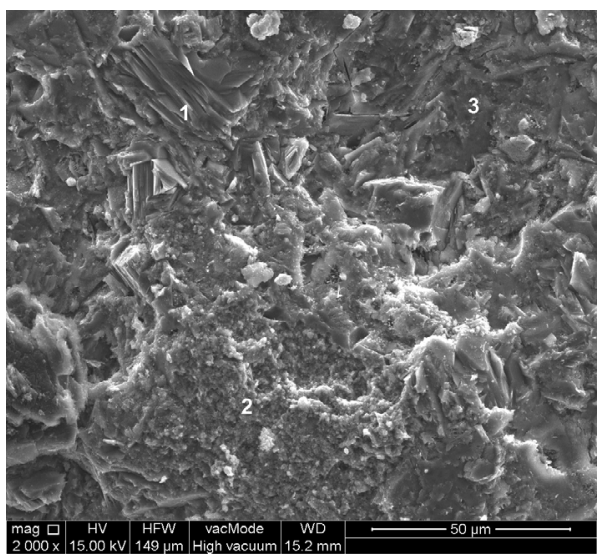

(a)

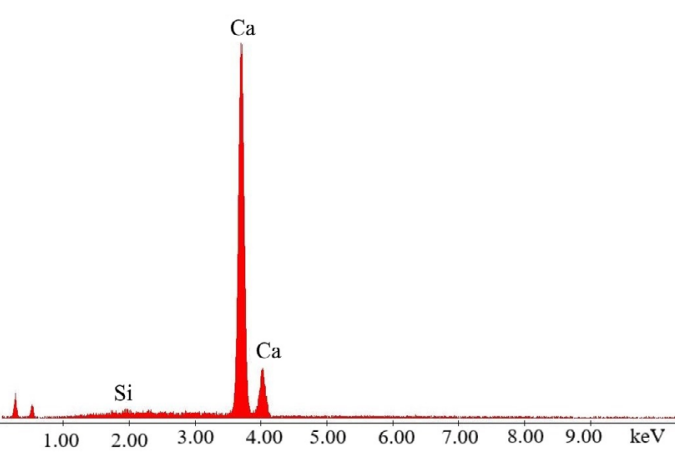

(b)

Fig. 3. Microstructure (a) and EDS spectra (b) of Portland cement paste without mineral additives after 28 days of hardening.

Information regarding the phase arrangement inside the material structure of modified cement matrix of concrete, containing zeolite and limestone, is essential. As seen from Fig. 4a, such a phase, as C-S-H which is the most important component of the cement matrix strengthens the structure and improves the fracture toughness of concrete. In contradistinction to C-S-H phase, large lamellar portlandite crystals can cause a significant weakening and greater susceptibility to the brittle destruction. 


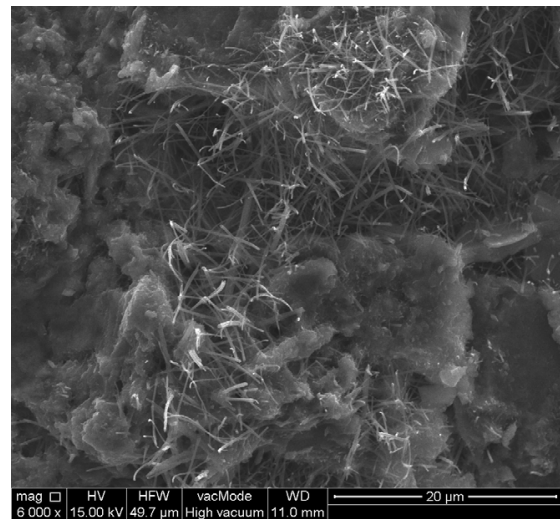

(a)

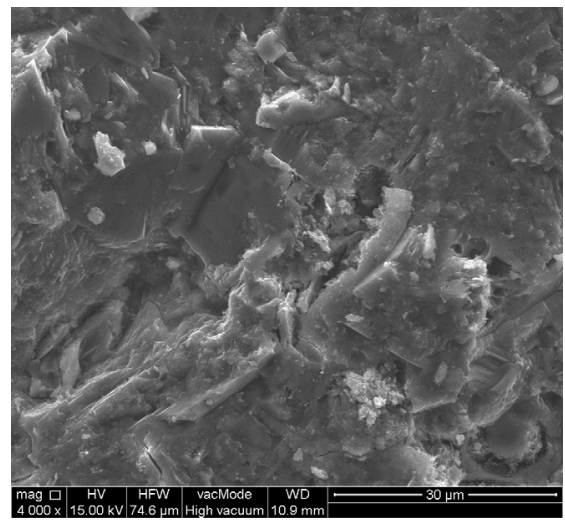

(c)

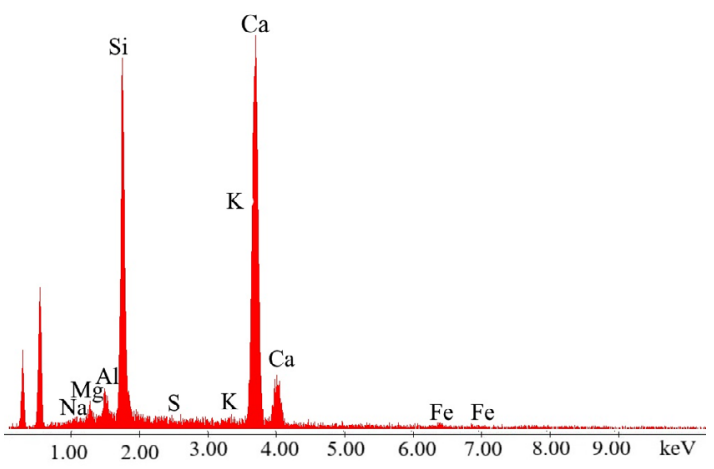

(b)

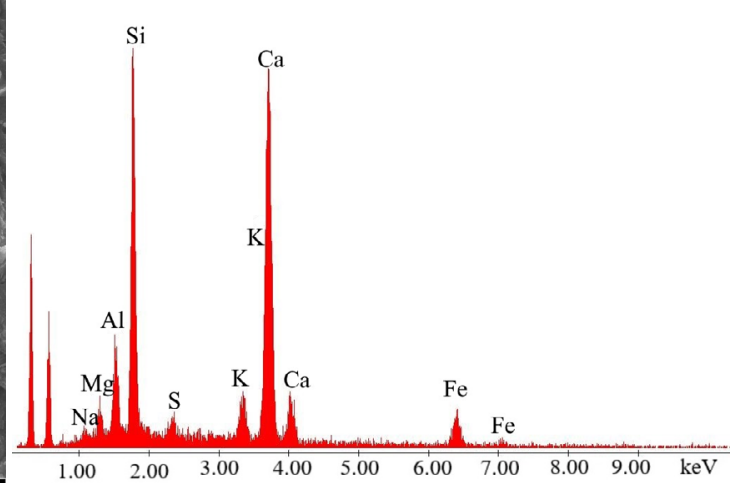

(d)

Fig. 4. Microstructure (a, c) and EDS spectra (b, d) of modified Portland cement paste containing zeolite and limestone after 28 days of hardening.

Fig. 4 shows, that zeolite and limestone cause a distinct replacement of weak calcium hydroxide $(\mathrm{CH})$ phase for a compact and durable phase C-S-H (Fig. 4a) as well as calcium hydroaluminate and hydrocarboaluminate (Fig. 4a,c). The concrete containing zeolite and limestone as well as superplasticizer and an air-entraining agent have lower amount of $\mathrm{CH}$ and due to adsorption modification of hydration products is characterized by denser structure and smaller pore size in comparison with the control concrete. It is also confirmed by the lowest value of water absorption of concrete ZLPA containing both mineral additives and chemical admixtures. It reduces from 3.94 mass. $\%$ for control concrete $\mathrm{C}$ to 2.97 mass. \% for modified concrete ZLPA. This compact concrete structure with pores of small diameter has a positive influence on both the strength and on the fracture properties of high-strength concrete.

\section{Conclusion}

The conducted tests revealed that the increase of the fracture properties is observed in concretes incorporating mineral additives such as zeolite and limestone modified with chemical admixtures. It is shown that consolidation of the concrete microstructure takes place as a result of limiting the amount of $\mathrm{CH}$ due to its reaction with active silica included in the zeolite and the formation of larger amounts of hydrated calcium silicates of the tobermorite type with the simultaneous absorption modification of hydrated products with 
chemical admixtures. As a result, the modified concretes containing zeolite and limestone can reach higher strength and are characterized by the higher fracture properties.

\section{References}

1. R.A. Einsfeld, M.S.L. Velasco, Cement Concrete Res. 36, 576 (2006)

2. G.A. Rao, B.R. Prasad, Cement Concrete Res. 32, 247 (2002)

3. A. Hillerborg, Mater. Struct. 18, 291 (1985)

4. B.H. Bharatkumar, B.K. Raghuprasad,. D.S. Ramachandramurthy, R. Narayanan, S. Gopalakrishnan, Mat. Struct. 38, 63 (2005)

5. L. Lam, Y.L. Wong, C.S. Poon, Cement Concrete Res. 28, 271 (1998)

6. E. Gartner, Cement Concrete Res. 34, 1489 (2004)

7. M. Valipour, F. Pargar, M. Shekarchi, S. Khani, Constr. Build. Mater. 41, 879 (2013)

8. T. Markiv, K. Sobol, M. Franus, W. Franus, Arch. Civ. Mech. Eng. 16, 554 (2016)

9. O. Hunyak, K. Sobol, T. Markiv, Mistobuduvannya ta terytorial'ne planuvannya, 54, 139 (2014)

10. P. Hawkins, P. Tennis, R. Detwiler, The use of limestone in Portland cement: a stateof-the-art review (Skokie, Portland Cement Association, 2003)

11. S. Solodkyy, O. Hunyak, T. Markiv, Avtomobil'ni dorohy i dorozhnye budivnytstvo, 98, 247 (2016)

12. BS EN 196, Method of testing cement. (British Standards Institution, London, 2016)

13. Rilem TC-50 FMC (Draft Recommendation). Mater. Struct. 18, 258 (1985)

14. DSTU B V.2.7-227. Metody vyznachennya kharakterystyky trishchynostiykosti (v yazkosti ruynuvannya) pry statychnomu navantazhenni (Ukrarhbudinform, Kyiv, 2010)

15. S. Solodkyy, Trishchynostiykist' betoniv na modyfikovanykh tsementakh (LPNU Publishing House, Lviv, 2008) 